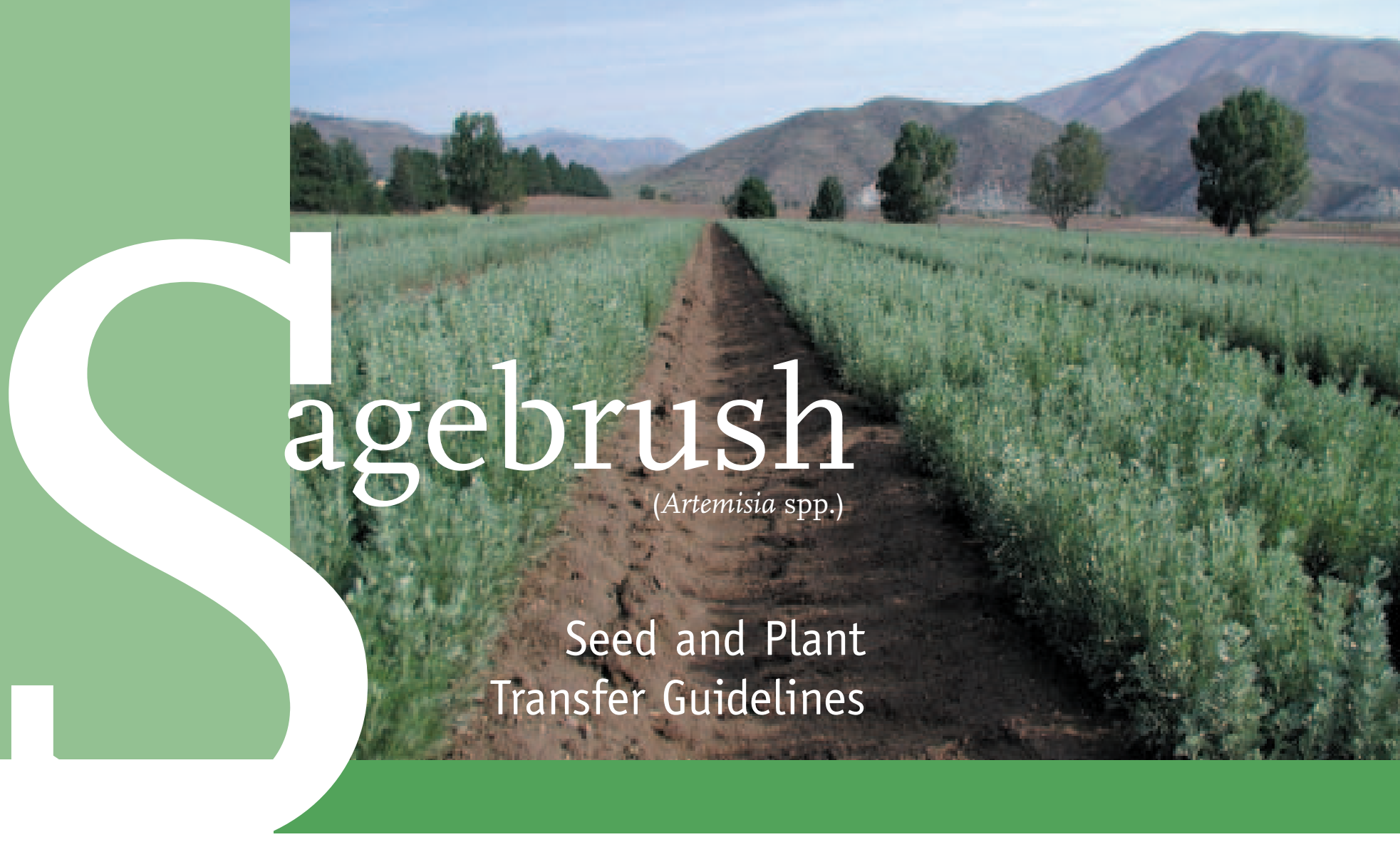

ABSTRACT

Mary F Mahalovich and E Durant McArthur |

Seed and plant transfer guidelines are offered for 11 species of sagebrush (Artemisia arbuscula, A. bigelovii, A. cana, A. rothrockii, A. longiloba, A. argillosa, A. rigida, A. nova, A. tripartita, A. pygmaea, and $A$. tridentata). These species constitute the true sagebrushes of the subgenus Tridentatae of Artemisia. The geographic distribution of each species serves as the geographic boundary for the 11 seed zones, with the additional restriction that seeds should not be moved farther than $483 \mathrm{~km}$ (300 mi) to their target planting site, and if less than $483 \mathrm{~km}$, not outside of their native distribution. For $A$. tridentata, seed transfer should ensure that subspecies are planted with respect to moisture and elevational gradients. For all other species, no additional transfer guidelines are proposed based on changes in elevation, but when local data suggest moisture gradients and ranges of elevation in excess of $458 \mathrm{~m}(1500 \mathrm{ft})$, conservative guidelines could further restrict seed transfer up 153 $\mathrm{m}(500 \mathrm{ft})$ in elevation, or down $305 \mathrm{~m}$ (1000 ft) in elevation, from the origin collection area. Correctly applied, seed and plant transfer guidelines minimize the risk of planting maladapted stock, increasing the survival and reproductive success to achieve restoration, rehabilitation, reclamation, and wildlife habitat improvement objectives.

KEY WORDS seed zones, adaptive traits, elevation gradients, ecotypes, ploidy, hybridization

NOMENCLATURE USDA NRCS (2004)

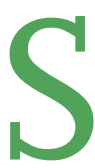

pecies of sagebrush have long been recognized as having an important ecological role on rangelands over much of the West. Sagebrush provides desirable browse and cover for livestock and wildlife, soil cover and stabilization, mining reclamation, medicinal purposes, and can play a pivotal role in fire relations. The degree of desirability of sagebrush depends upon the species and in some cases, the subspecies and varieties that are present (White and Currie 1984; McArthur and Stevens 2004).

This paper presents seed transfer guidelines for 11 species of sagebrush based on patterns of genetic variation and taxonomy that were published previously (McArthur and Plummer 1978; McArthur and others 1979, 1981; McArthur 1983; McArthur and Sanderson 1999a). Where data are lacking for some species, conservative transfer zones inferred from neighboring sagebrush species are recommended using additional information from planting, transplanting, and chemical variation data.

A crop of $1+0$ bareroot sagebrush growing at the USDA Forest Service Lucky Peak Nursery near Boise, Idaho. Photo by Clark Fleege, USDA Forest Service 
OVERVIEW OF THE ROLE OF SEED TRANSFER

Restoration, range rehabilitation, livestock forage, and wildlife habitat improvement carries the risk that planted shrubs will not be adapted to the environment in which they are planted. This risk can be minimized by limiting the distance that seeds and plants are moved from their origin both geographically and by elevation. These geographic and elevation limits known as seed transfer guidelines should be based on genetic differentiation of populations for traits reflecting adaptation to natural environments. Examples of adaptive traits in sagebrush species are drought resistance, reduced winter injury or cold hardiness, recovery from browsing (also chemical defense against herbivory), insect resistance, growth habit, root system development, response to fire, and allelopathy. Patterns of genetic variation in adaptive traits are based on the genetics, environment, and interaction of genetics and that environment for each species.

Seed transfer guidelines are withinspecies genetic management. Withinspecies management deals with management at the population or stand level (sometimes metapopulation) source of variation in the context of genetic structure for each species (Table 1). A common description of this source of variation applied to seed transfer guidelines is the seed zone. In other woody plants in the Intermountain West, mainly conifers, changes in elevation gradients may account for as much if not more of the observed patterns of genetic variation in adaptive traits (Rehfeldt 1991) and should be given consideration in developing seed transfer guidelines for woody plants. A model for shrub seed transfer zones, in the form of fourwing saltbush (Atriplex canescens (Pursh) Nutt. [Chenopodiaceae]), was recently published by Sanderson and McArthur (2004). Restoration, rehabilitation, riparian, and wildlife improvement programs, working together with natural genetic sys-
TABLE 1

Genetic structure of sources of variation within a species.

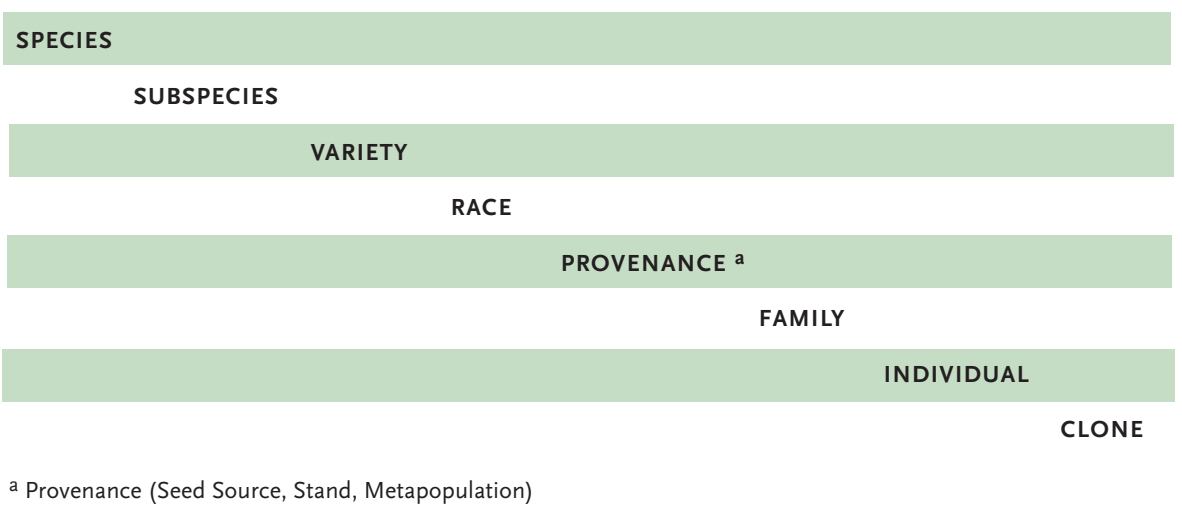

ulations to natural environments, maintain genetic diversity, and support longterm genetic conservation.

Populations of some species are characterized as having a specialist adaptive strategy if they are adapted to a relatively small segment of an environmental gradient, have most of their genetic variability among populations, or have a small or narrow geographic distribution. Conversely, populations of some species are characterized as having a generalist adaptive strategy if they are broadly adapted to an environmental gradient, have most of their genetic variability within populations, or generally have a large geographic distribution. Common-garden studies or transplantation experiments can help clarify whether species exhibit specialist or generalist adaptive strategies. When overall growth and morphology remain consistent with the source origin then a specialist adaptive strategy is inferred. Likewise, when populations of a species adjust to a common environment, by not rigidly upholding the characteristics of their source origin growth and morphology (exhibit plasticity), then a generalist adaptive strategy is assumed. Based on geography and available genetic data, $A$. arbuscula, A. cana, A. nova, and A. tridentata would be considered as having a generalist adaptive strategy. The more geographically restricted species, $A$. bigelovii, A. longiloba, A. rigida, A. tripartita, and $A$. rothrockii are likely to have a more intermediate to specialist adaptive strategy.

\section{Choice of Species}

The first, often-ignored step in seed transfer is choosing the appropriate species. Species distribution maps (Figures 1 to 6), forest and rangeland cover types, habitat typing, and ecological maps serve as useful tools for matching appropriate species to a particular planting site. Seed or plant material for a particular geographic location is determined by individual species' distributions (Artemisia arbuscula, A. bigelovii, A. cana, A. rothrockii, A. longiloba, A. argillosa, A. rigida, A. nova, A. tripartita, A. pygmaea, and $A$. tridentata) (Figures 1 to 6; Table 2). When determining species mix, if more than a single species occurs in a geographic location, it is more important to match a species to its native environment, than to choose a subspecies of big sagebrush for wildlife or livestock preferred forage. Sharp environmental gradients sort out sagebrush taxa on landscapes. For example, reciprocal transplant experiments have demonstrated the relative fitness of basin and mountain big sagebrush and their hybrids in a single small watershed (Wang and others 1997).

\section{Definition of a Seed Zone}

The geographic distribution of each sagebrush species serves as the geo- 
graphic boundary for each seed zone, with the additional restriction that seed or plants should not be moved farther than $483 \mathrm{~km}$ (300 mi) to its target planting site, and if less than $483 \mathrm{~km}$, plant material should not be moved outside of its native distribution. These relatively generous distances are justified by the wind-pollinated nature of the group wherein genetic makeup is often quite similar among populations of the same taxa. For example, some Wyoming big

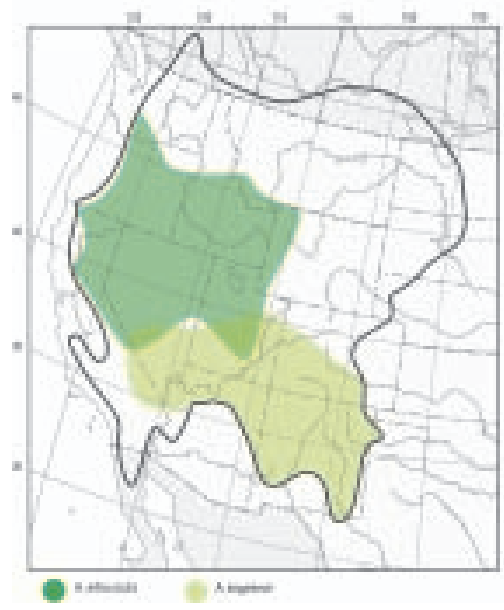

Figure 1. Distribution ranges of Artemisia arbuscula and A. bigelovii. The bold line is the distributional limit of the subgenus Tridentatae (McArthur and Plummer 1978).

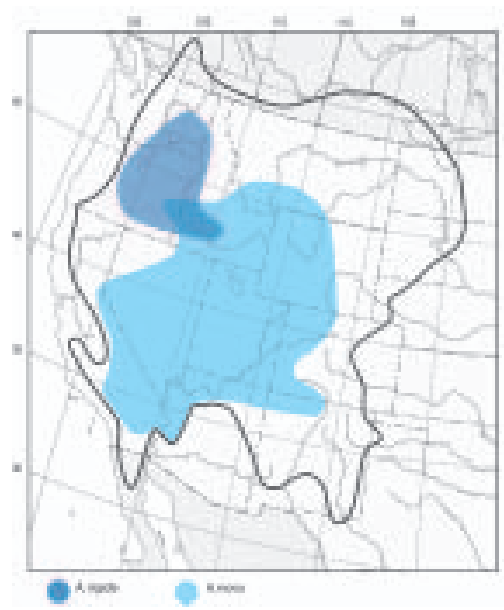

Figure 4. Distribution ranges of Artemisia rigida and $A$. nova. The bold line is the distributional limit of the subgenus Tridentatae (McArthur and Plummer 1978). sagebrush individual plants have genetic markers more in common with distant populations (McArthur and others 1998) than with local populations. Based on these designations, seed zone nomenclature for data management and seedlot identity control can correspond to the four- or five-digit code in the National List of Scientific Plant Names found in the PLANTS database (USDA NRCS 2004) (for example, the seed zone code for Artemisia arbuscula = ARAR8).

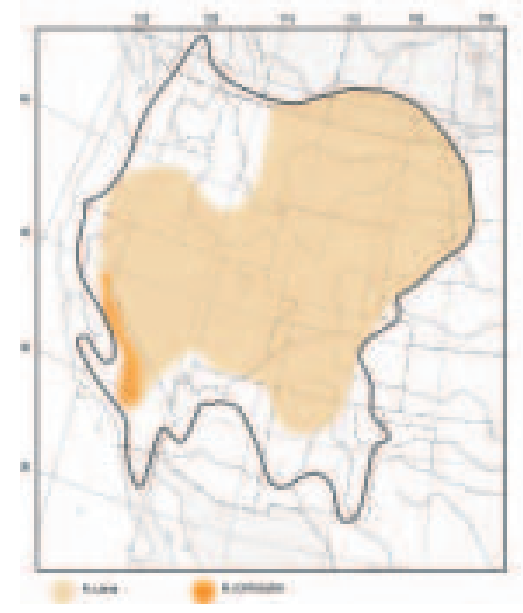

Figure 2. Distribution ranges of Artemisia cana and $A$. rothrockii. The bold line is the distributional limit of the subgenus Tridentatae (McArthur and Plummer 1978).

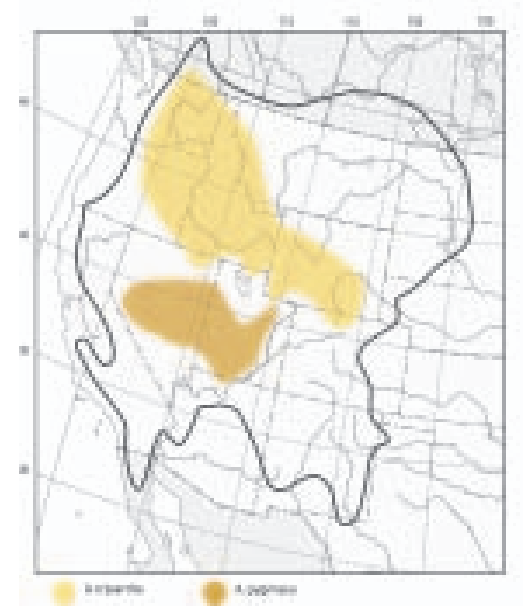

Figure 5. Distribution ranges of Artemisia tripartita and A. pygmaea. The bold line is the distributional limit of the subgenus Tridentatae (McArthur and Plummer 1978).
The USGS Water Resources Council HUC third field drainage (accounting unit) may also be a useful seed zone boundary for those administering seed zones (nurseries, seed warehouses), particularly for universal naming conventions and ease of database management. This third field drainage unit is typically smaller in size than most of the Artemisia species' distributions and is, therefore, a more conservative seed zone boundary. The fourth field drainage (cataloging

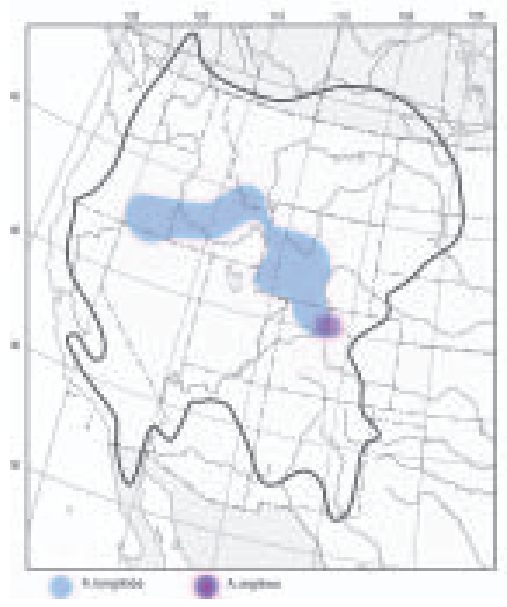

Figure 3. Distribution ranges of Artemisia longiloba and A. argillosa. The bold line is the distributional limit of the subgenus Tridentatae (McArthur and Plummer 1978).

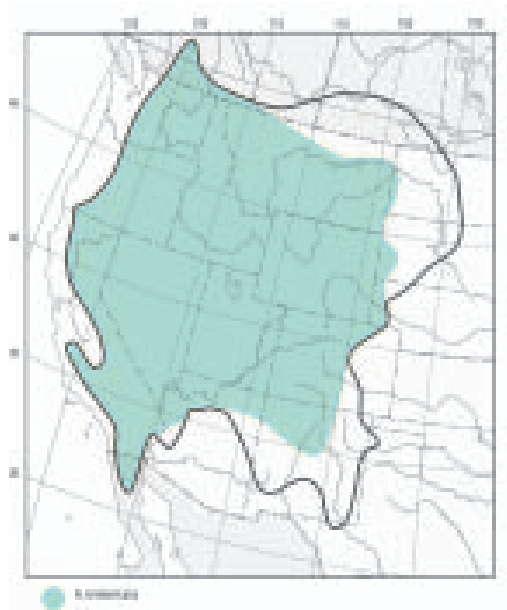

Figure 6. Distribution range of Artemisia tridentata. The bold line is the distributional limit of the subgenus Tridentatae (McArthur and Plummer 1978). 
Subgenus Tridentatae species with site adaptations and generalized distributions. ${ }^{a}$

\begin{tabular}{|c|c|c|c|c|c|c|}
\hline Species & Subspecies & Common name(s) & Site adaptation & Distribution & $\begin{array}{l}\text { Range of } \\
\text { elevation } \mathrm{m}(\mathrm{ft})\end{array}$ & $\begin{array}{l}\text { Chromosome } \\
\text { counts (ploidy) }\end{array}$ \\
\hline \multirow[t]{3}{*}{ A. arbuscula } & arbuscula & Low sagebrush & $\begin{array}{l}\text { Dry, sterile, rocky, } \\
\text { often shallow alkaline, } \\
\text { clay soils }\end{array}$ & $\begin{array}{l}\text { W Wyoming to } \\
\text { SC Washington } \\
\text { and N California }\end{array}$ & $\begin{array}{l}700 \text { to } 3780 \\
\text { (2300 to } 12400)\end{array}$ & $2 x, 4 x$ \\
\hline & longicaulis & $\begin{array}{l}\text { Lahonton low } \\
\text { sagebrush }\end{array}$ & $\begin{array}{l}\text { Dry, sterile, rocky, } \\
\text { often shallow alkaline, } \\
\text { clay soils in the } \\
\text { vicinity of old } \\
\text { Lake Lahonton }\end{array}$ & $\begin{array}{l}\text { NW Nevada and } \\
\text { neighboring Oregon } \\
\text { and California }\end{array}$ & $\begin{array}{l}1050 \text { to } 2000 \\
(3445 \text { to } 6560)\end{array}$ & $6 x$ \\
\hline & thermophila & $\begin{array}{l}\text { Hot springs } \\
\text { low sagebrush }\end{array}$ & $\begin{array}{l}\text { Spring-flooded, } \\
\text { summer-dry soils }\end{array}$ & $\begin{array}{l}\text { W Wyoming, } \\
\text { N Utah, and } \\
\text { E Idaho }\end{array}$ & $\begin{array}{l}1800 \text { to } 2500 \\
(5900 \text { to } 8200)\end{array}$ & $2 x$ \\
\hline \multirow[t]{2}{*}{ A. cana } & bolanderi & $\begin{array}{l}\text { Bolander silver } \\
\text { sagebrush }\end{array}$ & Alkaline basins & $\begin{array}{l}\text { E Oregon, W Nevada, } \\
\text { and N California }\end{array}$ & $\begin{array}{l}1525 \text { to } 3350 \\
\text { (5000 to } 11000 \text { ) }\end{array}$ & $2 x$ \\
\hline & cana & $\begin{array}{l}\text { Plains silver } \\
\text { sagebrush }\end{array}$ & $\begin{array}{l}\text { Loamy to sandy soils } \\
\text { of river bottoms }\end{array}$ & $\begin{array}{l}\text { E of Continental Divide, } \\
\text { Alberta and Manitoba } \\
\text { to Colorado, possibly in } \\
\text { Sevier County, Utah }\end{array}$ & $\begin{array}{l}1525 \text { to } 3350 \\
\text { (5000 to } 11000 \text { ) }\end{array}$ & $4 x, 8 x$ \\
\hline \multirow[t]{2}{*}{ A. nova } & nova & Black sagebrush & $\begin{array}{l}\text { Dry, shallow, stony soils; } \\
\text { some affinity for } \\
\text { calcareous soils }\end{array}$ & $\begin{array}{l}\text { SE Oregon to } \\
\text { SC Montana } \\
\text { to S California and } \\
\text { NW New Mexico }\end{array}$ & $\begin{array}{l}625 \text { to } 2990 \\
(2050 \text { to } 9800)\end{array}$ & $2 x, 4 x$ \\
\hline & duchesnicola & $\begin{array}{l}\text { Duchesne black } \\
\text { sagebrush }\end{array}$ & $\begin{array}{l}\text { Reddish clay soils of } \\
\text { Duchesne River } \\
\text { Formation }\end{array}$ & NE Utah & $\begin{array}{l}1700 \text { to } 1800 \\
\text { (5575 to } 5900)\end{array}$ & $6 x^{c}$ \\
\hline A. pygmaea & & Pygmy sagebrush & Desert calcareous soils & $\begin{array}{l}\text { C Nevada and } \\
\text { NE Utah to } \\
\text { N Arizona }\end{array}$ & $\begin{array}{l}1220 \text { to } 1830 \\
(4000 \text { to } 6000)\end{array}$ & $2 x$ \\
\hline A. rigida & & Stiff sagebrush & Rocky scablands & $\begin{array}{l}\text { E Oregon, WC Idaho, } \\
\text { and E Washington }\end{array}$ & $\begin{array}{l}230 \text { to } 2130 \\
\text { (755 to } 7000)\end{array}$ & $2 x, 4 x$ \\
\hline A. rothrockii & & Rothrock sagebrush & $\begin{array}{l}\text { Deep soils along forest } \\
\text { margins at high elevations } \\
\text { in Sierra Nevada } \\
\text { and outliers }\end{array}$ & California and Nevada & $\begin{array}{l}1000 \text { to } 4000 \\
\text { (3280 to } 13120)\end{array}$ & $4 x, 6 x$ \\
\hline
\end{tabular}




\begin{tabular}{|c|c|c|c|c|c|c|}
\hline Species & Subspecies & Common name(s) & Site adaptation & Distribution & $\begin{array}{l}\text { Range of } \\
\text { elevation } m(\mathrm{ft})\end{array}$ & $\begin{array}{l}\text { Chromosome } \\
\text { counts (ploidy) b }\end{array}$ \\
\hline \multirow[t]{5}{*}{ A. tridentata } & spiciformis $\mathrm{d}$ & $\begin{array}{l}\text { Snowbank big } \\
\text { sagebrush }\end{array}$ & $\begin{array}{l}\text { High mountain areas } \\
\text { or associated with } \\
\text { A. cana ssp. viscidula } \\
\text { but in slightly drier areas }\end{array}$ & $\begin{array}{l}\text { Wyoming, Idaho, } \\
\text { Colorado, and Utah }\end{array}$ & $\begin{array}{l}2075 \text { to } 3050 \\
(6800 \text { to } 10000)\end{array}$ & $2 x, 4 x$ \\
\hline & tridentata & Basin big sagebrush & $\begin{array}{l}\text { Deep, dry, fertile soils } \\
\text { of valleys and foothills }\end{array}$ & $\begin{array}{l}\text { British Columbia and } \\
\text { Montana to New Mexico } \\
\text { and Baja California }\end{array}$ & $\begin{array}{l}610 \text { to } 2140 \\
(2000 \text { to } 7020)\end{array}$ & $2 x, 4 x$ \\
\hline & vaseyana & $\begin{array}{l}\text { Mountain big } \\
\text { sagebrush }\end{array}$ & $\begin{array}{l}\text { Deep, well-drained soils } \\
\text { often with summer } \\
\text { moisture available } \\
\text { in mountains and foothills }\end{array}$ & $\begin{array}{l}\text { British Columiba and } \\
\text { Montana to S California } \\
\text { and N New Mexico }\end{array}$ & $\begin{array}{l}780 \text { to } 3100 \\
(2560 \text { to } 10170)\end{array}$ & $2 x, 4 x$ \\
\hline & wyomingensis & $\begin{array}{l}\text { Wyoming big } \\
\text { sagebrush }\end{array}$ & $\begin{array}{l}\text { Shallower, well-drained, } \\
\text { hottest soils. Utah: often } \\
\text { underlain by a caliche or } \\
\text { silica layer in valleys } \\
\text { and foothills }\end{array}$ & $\begin{array}{l}\text { North Dakota and } \\
\text { Washington to Arizona } \\
\text { and New Mexico }\end{array}$ & $\begin{array}{l}1520 \text { to } 2150 \\
(2500 \text { to } 7260)\end{array}$ & $2 x, 4 x$ \\
\hline & xericensis & Xeric big sagebrush & Basaltic and granitic soils & WC Idaho & $\begin{array}{l}1520 \text { to } 2140 \\
\text { (2500 to } 7260)\end{array}$ & $4 x$ \\
\hline \multirow[t]{2}{*}{ A. tripartita } & rupicola & $\begin{array}{l}\text { Wyoming threetip } \\
\text { sagebrush }\end{array}$ & Rocky knolls & Wyoming & $\begin{array}{l}1100 \text { to } 2300 \\
(3390 \text { to } 7085)\end{array}$ & $2 x$ \\
\hline & tripartita & $\begin{array}{l}\text { Tall threetip } \\
\text { sagebrush }\end{array}$ & $\begin{array}{l}\text { Moderate-to-deep, } \\
\text { well-drained soils }\end{array}$ & $\begin{array}{l}\text { E Washington and } \\
\text { W Montana to } \\
\text { N Nevada and N Utah }\end{array}$ & $\begin{array}{l}1100 \text { to } 2300 \\
(3390 \text { to } 7085)\end{array}$ & $2 x, 4 x$ \\
\hline \multicolumn{7}{|c|}{ a General sources: Beetle (1960), Winward (1970), McArthur and Plummer (1978), Winward (1980), Harvey (1981), McArthur (1983, 1994), Winward and McArthur (1995). } \\
\hline \multicolumn{7}{|c|}{$\begin{array}{l}\text { b See McArthur and Sanderson (1999a) for details except for A. arbuscula ssp. thermophila and A. tripartita ssp. rupicola, which were recently determined to be diploid ( } 2 x \text { ) by } \\
\text { McArthur and Sanderson (unpublished). }\end{array}$} \\
\hline
\end{tabular}

unit) has formerly been recommended as a seed zone for some USDA Forest Service Native Plants Programs (USDA Forest Service 1995). Though overly conservative and not representative of the more generalist and intermediate adaptive strategies of Artemisia spp., this sub-basin cataloguing unit is a useful tool for developing seed collection strategies to ensure that broad genetic samples are collected over time and to further minimize the negative consequences of depleting a local seed source by over-collecting in one or more years.

Whether using the species geographic boundary or the USGS Water Resources Council HUC third field drainage as the seed zone boundary, federal, state, and local agencies and conservation organizations should adopt a consist format among participants. As additional research takes an in-depth look at more populations within a species and specifically addresses the objective of developing seed transfer guidelines, seed zone designations and seed transfer guidelines may be updated to reflect newer findings.

\section{Choice of Subspecies}

Varying species and subspecies may have very different seed transfer guidelines within a watershed depending on the microhabitat. After choosing the appropriate seed zone and species mix, choice of an appropriate subspecies is the next critical step in seed transfer (Table 2), particularly for A. tridentata. Basin big sagebrush (ssp. tridentata) is recommended for foothills and valley floors with deep, seasonally dry soils. Mountain big sagebrush (ssp. vaseyana) is appropriate for foothills and mountain areas with deep soils-usually with summer moisture events. Wyoming big sagebrush (ssp. wyomingensis) is a good choice for foothills, plains, and mountain basins with shallow, rocky soils, or if caliche is present. Timberline or snow- 


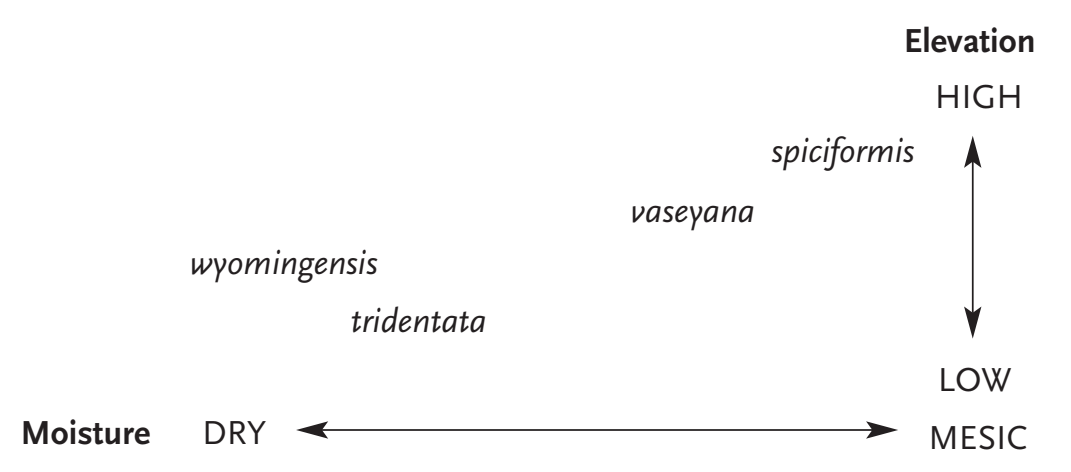

Figure 7. Artemisa tridentata subspecies occurrence by moisture and elevational gradients (McArthur 1983).

bank big sagebrush (ssp. spiciformis) is suited to high mountain areas. Xeric big sagebrush (ssp. xericensis) is suitable for dry slopes and draws in southwestern Idaho where it is a restricted endemic. Within a given drainage as many as three subspecies may be needed for planting, depending upon moisture gradients and elevation (Figure 7).

\section{OTHER FACTORS GUIDING SEED TRANSFER}

\section{Ploidy Levels}

Polyploidy is an important mechanism in the differentiation and adaptation of Artemisia species in general and Tridentatae species in particular. Polyploidy can influence fertility and plant vigor. Polyploidy may mask the interpretation of adaptive traits inherited in a quantitative fashion and could be more significant than geographic source or seed zone. Mixed ploidy matings can represent outbreeding depression (matings among genetically different populations resulting in progeny with less fitness) and sterility because of unbalanced meiotic segregation. In general, polyploids have higher heterozygosity than diploids (McArthur 1989; Cronn and Wendel 2003).

Tridentatae species not only exhibit broad general polyploidy patterns but also patterns that are evident at ecotonal interfaces and within populations. Ploidy levels
(1932) suggested that polyploids were better adapted to extreme ecological environments than were their diploid relatives. This seems to be the case with the sagebrushes and some other western North American shrub complexes (Sanderson and others 1989; McArthur and Sanderson 1999a). Autopolyploidy, the form of polyploidy in the Tridentatae (McArthur and others 1981), alters cytologic, biochemical, genetic, and physiological, and developmental characters, which may provide tolerance beyond limits of diploid progenitors (Levin 1983). In contrast to the norm in herbaceous plants, where plant size and growth rate in polyploids are typically larger than diploids, Artemisia spp. show a contrasting phenomenon; the polyploids are smaller. This is believed to occur in these woody plants as a result of increased cellulose as ploidy levels increase, thus metabolism and growth are retarded, lowering growth rates and increasing drought tolerance.

Phylogenetic and cytological studies reveal multiple ploidy levels among the 11 species of sagebrush (Table 2). The genus has 2 principal base chromosome numbers $\mathrm{x}=8$ and $\mathrm{x}=9$. However, $\mathrm{x}=9$ is by far the most common and is the base number for the sagebrushes of North America (= subgenus Tridentatae) (Vallès and McArthur 2001). Polyploidy is common, $2 \mathrm{x}$ to $8 \mathrm{x}$ in North American sagebrush and up to $12 \mathrm{x}$ for the genus. Polyploidy also exists within populations (McArthur and Sanderson 1999a). When drought tolerance is critical for planting success and capturing a site, ploidy level should be given consideration for seed source choices. For example, Wyoming big sagebrush (A. tridentata ssp. wyomingeneis) is tetraploid $(4 \mathrm{x})$ and is adapted to drier sites than are the predominately diploid basin and mountain big sagebrushes.

\section{Introgression and Interspecific Hybridization}

In the case of seed transfer, interspecific hybridization is viewed as a naturally occurring process leading to increased diversity and the promotion of speciation over time. Some researchers and practitioners recommend the avoidance of all hybrid zones for seed collection both for restoration and revegetation projects. These naturally occurring hybrid zones, however, have allowed A. tridentata to be widely adaptable. Hybrid zones are suitable for seed collection for restoration, as hybridization contributes to the versatility of Artemisia spp. (McArthur and Sanderson 1999b).

Even if seed transfer guidelines prohibited the sampling and planting of hybrid areas, it must be acknowledged that hybridization is a naturally occurring process and will continue on its own regardless of management direction and perhaps will even be promoted as the increasing urban interface contains nonlocal sagebrush species in landscape settings. Hybrid areas should be sampled for seed collection and actively restored within the context of a target watershed.

Cronn and Wendell (2003) call for a multidisciplinary approach to investigating the extent of hybridization in evolutionary biology, as inferences concerning the frequency and importance of hybridization are always underestimated. In the meantime, practical guidelines for seed and plant movement are still needed. They should be reasonable but not unduly limiting until introgression and interspecific hybridization are more fully understood.

Both polyploidization and hybridization have shaped the differentiation and 
patterns of genetic variation in the Tridentatae (McArthur and others 1988; McArthur and Sanderson 1999a). Hybrid zones are likely the source for differentiation of new genetic combinations that were able to exploit new habitats as climates changed in the Pliocene and Pleistocene epochs and that will be able to adopt to new habitats during predicted changes in the near future (Neilson and Drapek 1998).

\section{Elevation Movement}

When local conditions contain moisture gradients and ranges of elevation in excess of $458 \mathrm{~m}$ (1500 ft), conservative guidelines further restrict seed transfer up $153 \mathrm{~m}(500 \mathrm{ft})$ in elevation, or down $305 \mathrm{~m}$ (1000 ft) in elevation, from the origin collection area for all species except A. tridentata (Figure 7). Seeds from western shrub species show ecotypic differences in seed germination. Rapid germination under snow pack in high mountain environments from low elevation or warm desert seed sources may lead toward decreased seedling survival and an increase in damage due to frost and damping-off (Meyer 1990). Germination patterns in big sagebrush populations are dependent on habitat; movement of seed for rehabilitation or restoration plantings would be better served by using seed from similar habitats to ensure initial germination success (Meyer and others 1990; Meyer and Monsen 1992).

\section{Drought Tolerance}

In addition to ploidy level, choose a drought-tolerant ecotype such as upland Wyoming big sagebrush, which is more drought hardy than basin big sagebrush, which is adapted to deeper soils. Basin big sagebrush is a prolific seed producer and its seed is readily available, but planting basin big sagebrush on uplands sites is risky. Wyoming big sagebrush is also the subspecies of choice for droughty, mineralized, or coal-mined reclamation lands.

\section{When Local Sources Are Not Available}

In experiments where wild seedlings of several accessions of $A$. tridentata ssp. tridentata, A. nova, A. cana, and $A$. bigelovii were transplanted from one area to another, the results of Plummer and others (1968) and Plummer (1977) suggest that if seeds must be brought in from some distance, it is best to get them from a harsher climate or more northerly location.

\section{Managing Genetic Diversity through Collections}

For all species, collect from at least 30 unrelated plants, separated by a minimum of $30 \mathrm{~m}(100 \mathrm{ft})$ in distance. An equal number of seeds should be collected per plant. Each seed lot should not span more than $92 \mathrm{~m}$ (300 ft), nor should the collection area exceed $0.5 \mathrm{~km}$ (1640 $\mathrm{ft}$ ), to optimize its transfer capabilities.

SUMMARY

Seed transfer guidelines first call for the selection of appropriate species and sometimes an associated species mix for a target planting location based on the geographic distribution or seed zone for each species. Within each species, additional considerations are offered for appropriate subspecies based on elevation and moisture gradients for $A$. tridentata. Elevation transfers are more liberal for moving seed sources down in elevation than up in elevation. Specific ecotypes or ploidy level may also be useful for droughty areas and mineral soils for choosing particular seed sources. Though some species are more consistent seed producers, adopting these seed transfer guidelines, partnered with monitoring the frequency of seed crops (every 1 to $4 \mathrm{y}$ ), will benefit seed procurement activities, management of genetic diversity, and encouraging successful planting programs.
This work was funded in part by USDA Forest Service National Fire Plan and by the USDI Bureau of Land Management Great Basin Native Plant Selection and Increase Project. The authors thank the following colleagues for their discussions on seed zone issues: Stewart Sanderson, Nancy Shaw, Susan Meyer, Steve Monsen, Mike Pellant, and Rich Cronn and in appreciation to Bob Schrenk for championing the importance of genetics and seed transfer guidelines in native plants.

REFERENCES

Beetle AA. 1959. New names within the section Tridentatae of Artemisia. Rhodora 61:82-85.

Beetle AA. 1960. A study of sagebrush—Section Tridentatae of Artemisia. Laramie (WY): University of Wyoming, Wyoming Agricultural Experiment Station. Bulletin 368. 83 p.

Cronn R, Wendel JF. 2003. Research review. Cryptic trysts, genomic mergers, and plant speciation. New Phytologist 161:133-142.

Hagerup O. 1932. Über Polyploidie in Beziehung su Klima, Ökologie und Phylogenie. Hereditas 16:19-40.

Harvey S). 1981. Life history and reproductive strategies in Artemisia [MSc thesis]. Bozeman (MT): Montana State University. 132 p.

Levin WH. 1983. Polyploidy and novelty in flowering plants. American Naturalist 122:1-25.

McArthur ED. 1983. Taxonomy, origin, and distribution of big sagebrush (Artemisia tridentata) and allies (subgenus Tridentatae). In: Johnson KL, editor. Proceedings, first Utah shrub ecology workshop; 1981 Sep 9-10; Ephraim, UT. Logan (UT): Utah State University, College of Natural Resources. p 3-13.

McArthur ED. 1989. Breeding systems in shrubs. In: McKell CM, editor. The biology and utilization of shrubs. New York (NY): Academic Press Inc. p 341-361.

McArthur ED. 1994. Ecology, distribution, and values of sagebrush within the Intermountain region. In: Monsen SB, Kitchen SG, compilers. Proceedings, ecology and management of annual rangelands. Ogden (UT): 
USDA Forest Service, Intermountain Research Station. General Technical Report INT-GTR-313. p 347-351.

McArthur ED, Plummer AP. 1978. Biogeography and management of native western shrubs: a case study, section Tridentatae of Artemisia. Great Basin Naturalist Memoirs 2:229-243.

McArthur ED, Sanderson SC. 1999a. Cytogeography and chromosome evolution of subgenus Tridentatae of Artemisia (Asteraceae). American Journal of Botany 86:1754-1775.

McArthur ED, Sanderson SC. 1999b. Ecotones: introduction, scale, and big sagebrush example. In: McArthur ED, Ostler WK, Wambolt CL, compilers. Proceedings, shrubland ecotones; 1998 Aug 12-14, Ephraim, UT. Ogden (UT): USDA Forest Service, Rocky Mountain Research Station. Proceedings RMRS-P-11. p 3-8.

McArthur ED, Stevens R. 2004. Composite shrubs. In: Monsen SB, Stevens R, Shaw NL, compilers. Restoring western ranges and wildlands. Fort Collins (CO): USDA Forest Service, Rocky Mountain Research Station. General Technical Report. RMRS-GTR-136. p 493-537.

McArthur ED, Blauer AC, Plummer AP, Stevens R. 1979. Characteristics and hybridization of important intermountain shrubs. III. Sunflower family. Ogden (UT): USDA Forest Service, Intermountain Forest and Range Experiment Station. Research Paper INT-220. 82 p.

McArthur ED, Pope CL, Freeman DC. 1981. Chromosomal studies of subgenus Tridentatae of Artemisia: evidence for autopolyploidy. American Journal of Botany 68:589-605.

McArthur ED, Welch BL, Sanderson SC. 1988. Natural and artificial hybridization between big sagebrush subspecies. Journal of Heredity 79:268-276.

McArthur ED, Mudge J, Van Buren R, Andersen WR, Sanderson SC, Babbel DG. 1998. Randomly amplified polymorphic DNA analysis (RAPD) of Artemisia subgenus Tridentatae species and hybrids. Great Basin Naturalist 58:12-27.

Meyer SE. 1990. Seed source differences in germination under snow pack in northern Utah. In: Fifth Billings symposium on disturbed land rehabilitation. Volume I. Hardrock waste, analytical and revegetation; $1990 \mathrm{Mar}$ 25-30; Billings, MT. p 184-191.

Meyer SE, Monsen SB. 1992. Big sagebrush germination patterns: subspecies and population dif-
Meyer SE, Monsen SB, McArthur ED. 1990. Germination response of Artemisia tridentata (Asteraceae) to light and chill: patterns of between-population variation. Botanical Gazette 151:176-183.

Neilson RP, Drapek RJ. 1998. Potential complex biosphere responses to transient global warming. Global Change Biology 4:505-521.

Plummer AP. 1977. Revegetation of disturbed intermountain area sites. In: Thames JT, editor. Reclamation of disturbed land in the southwest. Tucson (AZ): University of Arizona Press. p 302-339.

Plummer AP, Christensen DR, Monsen SB. 1968. Restoring big game range in Utah. Salt Lake City (UT): Utah Division of Fish and Game. Publication 68-3. 183 p.

Rehfeldt GE. 1991. Gene resource management: using models of genetic variation in silviculture. In: Miller D, Murphy D, editors. Proceedings, genetics/silviculture workshop; 1990 Aug 27-31; Wenatchee, WA. Washington (DC): USDA Forest Service, Timber Management. p 31-44.

Rydberg PA. 1916. Artemisia and Artemisiastrum. North American Flora 34:244-285.

Sanderson SC, McArthur ED. 2004. Fourwing saltbush (Atriplex canescens) seed transfer zones. Fort Collins (CO): USDA Forest Service, Rocky Mountain Research Station. General Technical Report RMRS-GTR-125. 10 p.

Sanderson SC, McArthur ED, Stutz HC. 1989. A relationship between polyploidy and habitat in western shrub species. In: Wallace A, McArthur ED, Haferkamp MR, compilers. Proceedings, symposium on shrub ecophysiology and biotechnology; 1987 Jun 30-Jul 2; Logan, UT. Ogden (UT): USDA Forest Service, Intermountain Research Station. General Technical Report INT-256. p 23-30.

USDA Forest Service. 1995. Northern Region native plant handbook. A guide to revegetation with native plants. Missoula (MT): USDA Forest Service, Northern Region. 99 p. USDA NRCS. 2004. The PLANTS database, version 3.5. URL: http://plants.usda.gov (accessed 15 Sep 2004). Baton Rouge (LA): National Plant Data Center.

Vallès J, McArthur ED. 2001. Artemisia systematics and phylogeny: cytogenetic and molecular insights. In: McArthur ED, Fairbanks DJ, compilers. Proceedings, shrubland ecosystem genetics and biodiversity; 2000 Jun 13-15,
Provo, UT. Ogden (UT): USDA Forest Service, Rocky Mountain Research Station. Proceedings RMRS-P-21. p 67-74.

Wang H, McArthur ED, Sanderson SC, Graham JH, Freeman DC. 1997. Narrow hybrid zone between two subspecies of big sagebrush (Artemisia tridentata: Asteraceae). IV. Reciprocal transplant experiments. Evolution 51:95-102.

Welsh SL, Goodrich S. 1995. Plant novelties in Lepidium (Cruciferae) and Artemisia (Compositae) from the Uinta Basin, Utah. Great Basin Naturalist 55:359-362.

White RS, Currie PO. 1984. Phenological development and water relations in plains silver sagebrush. Journal of Range Management 37:503-507.

Winward AH. 1970. Taxonomic and ecological relationships of the big sagebrush complex in Idaho [PhD dissertation]. Moscow (ID): University of Idaho. $80 \mathrm{p}$.

Winward AH. 1980. Taxonomy and ecology of sagebrush in Oregon. Corvallis (OR): Oregon State University Agriculture Experiment Station. Bulletin No. 642. 15 p.

Winward AH, McArthur ED. 1995. Lahontan sagebrush (Artemisia arbuscula ssp. longicaulis): a new taxon. Great Basin Naturalist 55:151-157.

\section{AUTHOR INFORMATION}

Mary F Mahalovich

Regional Geneticist

USDA Forest Service

Northern, Rocky Mountain,

Southwestern, and

Intermountain Regions

Forestry Sciences Laboratory

1221 South Main Street

Moscow, ID 83843

mmahalovich@fs.fed.us

E Durant McArthur

Project Leader and

Research Geneticist

USDA Forest Service

Shrub Sciences Laboratory

Rocky Mountain

Research Station

735 North 500 East

Provo, UT 84606

dmcarthur@fs.fed.us 